\title{
TRANSFORMATION OF THE AUSTRALIAN PUBLIC SECTOR AND ENVIRONMENTAL ACCOUNTING PRACTICES: THE CASE OF WATER IN 2001
}

\author{
David R Moore ${ }^{1}$ \\ The University of Sydney
}

\begin{abstract}
This paper analyses a case study undertaken in 2001 of a Victorian public sector water utility to examine the implications of public sector 'modernisation' reforms of the 1980s and 1990s for the adoption of environmental accounting (EA) procedures within the Victorian water industry. Legislative reforms have resulted in the allocation of overhead costs for the purpose of segmented reporting and to measure the "full cost' of departments. This was consistent with the "managerialist”, "marketization” and "strategic” phases of public sector 'modernisation' reforms, but did not measure the full economic (environmental) cost. The application of full cost recovery for the purpose of efficiency was further evidence of the impact of public sector modernisation reforms but did not extend to the recovery of externalities. Private environmental costs were traced and integrated into direct cost categories, consistent with the philosophy of managerialism. Costs were measured for the purposes of promoting the contracting out of selected services and functions. There was limited adoption of environmental accounting practices, due to the absence of environmental accounting measurement guidelines. Staff interviewed recognized the importance of environmental issues, but were yet to appreciate the benefits of adopting EA practices. Subsequent to the case study, the Victorian government introduced legislation that required water authorities to make provisions for environmental contributions, a step towards accounting for environmental externalities. This was the beginning of the "sustainability" phase of public sector 'modernisation' reforms.
\end{abstract}

Keywords Australian public sector reform; Water industry; Managerialism; Cost Recovery; Externalities; Environmental Accounting.

\section{INTRODUCTION}

An accounting for water in 2008 is recognized as a critical component in the management of water by both Commonwealth and State governments in Australia (NWC, 2005; VGDSE,

\footnotetext{
${ }^{1}$ The author gratefully acknowledges the detailed and constructive feedback from Associate Professor Geoff Frost, Professor James Guthrie, two anonymous reviewers and participants at the $6^{\text {th }}$ Australasian Conference on Social and Environmental Accounting Research, University of Sydney, December, 2007. The author would also like to acknowledge the encouragement and support of Ms. Sandra Van der Laan and Dr. Cornelia Beck in completing this paper.
} 
2006). The Commonwealth of Australia National Water Commission (NWC) ${ }^{2}$ has identified an integral role for accounting of water to ensure that water is provided to meet environmental requirements that enable the building of trust and confidence about water management in the community (NWC, 2005). At a state government level, the Victorian Government Department of Sustainability and the Environment (VGDSE) ${ }^{3}$ has highlighted that improved systems and procedures for accounting for water are essential for a high degree of management accountability (VGDSE, 2006). The recognition of the importance of accounting for water was also emerging in the period leading up to 2001. In 1994, the Council of Australian Governments (COAG) recognized a future role for environmental accounting (EA) due to the need to address the economic, environmental and social implications of future water reform (NCC, 1998 p.103). In 1998, an OECD (Organisation for Economic Co-operation and Development) evaluation of Australia's environmental performance recommended that Australia increases the internalization of environmental costs ${ }^{4}$ into resource use (OECD, 1998). Within Victoria, the Parliament of Victoria Environment and Natural Resources Committee recommended that additional work was required into the full accounting of the costs and benefits of re-use of urban waste-water due to the associated environmental benefits (The Parliament of Victoria, 2001).

By 2001, Victorian water authorities were therefore beginning to account for the environmental impacts of their operations due to recognition of the importance of EA by COAG, the OECD and the Parliament of Victoria, whilst having experienced significant "modernization" changes that emphasized efficiency and cost recovery. The motivation for this study is to provide an understanding as to the implications of modernization in the public sector for accounting for water within the Victorian water industry. Ball and Grubnic (2007, p. 258) highlight the need for research that examines "how the regulatory frameworks under which the public sector operates can be changed so that sustainability accounting is integrated into mainstream accounting”. As at 2001, research into the understanding and transformation of EA procedures within the Australian public sector had been limited to NSW (Gibson \& Guthrie, 19955; Frost \& Toh, 1998a, 1998b), whilst an analysis of environmental disclosures had been undertaken within the Australian commonwealth public sector (Burritt \& Welch, 1997a, 1997b). Since 2001, research into EA procedures in the public sector has focused on Europe. In Spain, Larrinaga-Gonzalez and Bebbington (2001) undertook a case study of the implementation of EA in a Spanish electricity utility whilst Ball (2005) examined Environmental accounting in UK local government, Ball et al., (2006) examined the potential for 'sustainability reporting' in the context of waste management contracts let under the Private Finance Initiative (PFI), Ball and Grubnic (2007) provided a summary of sustainability accounting initiatives in the UK public sector whilst Cashman and Lewis (2007) examined sustainable development in the privatized UK water

\footnotetext{
2 The NWC was established under the National Water Commission Act 2004 to provide advice to the Council of Australian Governments (COAG) and the Australian Government on national water issues http://www.nwc.gov.au/about/index.cfm (Accessed 10/9/2007).

${ }^{3}$ The Department of Sustainability and Environment is a Victorian government agency responsible for promoting and managing the sustainability of the natural and built environments http://www.dse.vic.gov.au/dse/dsencor.nsf/Home+Page/722B4B7ECAC238FCCA256E7D007EA857?open (Accessed 10/9/2007)

${ }^{4}$ Environmental costs have two dimensions: i) "private costs" - conventional (direct) costs; hidden costs; contingent costs; relationship and image costs; and ii) “societal costs” - externalities (Parker, 2000b; Gray \& Bebbington, 2001; ICAA, 2003)

${ }^{5}$ Gibson and Guthrie (1995) examined environmental disclosures in annual reports (EDAR) of Australian public and private sector organisations.
} 
industry. Within Victoria, research has focused upon the role of EA in local government (Douglass, 1996). Victoria is an appropriate focal point of research because of its status as "an early and radical adopter of new public management techniques” (Carlin, 2003, p. 73).

In order to examine the implications of modernization in the public sector for accounting for water within the Victorian water industry, the paper proceeds as follows. Section 2 examines the development of EA practices in the public sector and Victorian and Commonwealth public sector reforms of the Victorian water industry up to and including 2001. Section 3 outlines the case study organization and the research method approach. Section 4 analyses the information obtained from the case study interviews undertaken in 2001. As the initial case study was undertaken in 2001, Section 5 is a postscript, examining EA developments in the Victorian water industry subsequent to 2001 and providing a discussion and concluding comments.

\section{THE DEVELOPMENT OF ENVIRONMENTAL ACCOUNTING PRACTICES AND PUBLIC SECTOR MODERNIZATION}

Within Australia, there has been limited research into the role of accounting and (risk) management within the water industry (e.g. Sadler, 1998; Walker et al., 2000; Dalgleish \& Cooper, 2005), as compared to the United Kingdom where there has been extensive research into the privatization of water utilities (e.g. Ogden 1995a, 1995b, 1997; Ogden \& Anderson, 1999; Ogden \& Watson, 1996, 1999; Ogden \& Clarke, 2005; Shaoul, 1997a, 1997b; Letza and Smallman, 2001). This paper seeks to contribute to the existing body of knowledge by providing an understanding of the implications of "modernization"6 in the public sector for the transformation of EA practices with specific reference to the Victorian water industry. This section commences with an overview of the development of EA practices in the public sector whilst section 2.2 examines public sector modernization with specific reference to the Victorian water industry.

\section{The development of environmental accounting practices in the public sector}

$\mathrm{EA}^{7}$ relates to the provision of environmental-performance related information to stakeholders both within, and outside, the organisation (ICAA, 2003). Its purpose is to recognize and mitigate the negative environmental effects of conventional accounting practice (Gray \& Bebbington, 2001). The importance of EA as an integral part of public sector reform in Victoria was highlighted by two separate Victorian parliamentary enquiries into EA and reporting which recognised that an EA system is necessary for an adequate Environmental Management System (EMS) as both result in higher quality environmental reporting (The Parliament of Victoria, 2002, p. 165). A Victorian Auditor-General's report into the performance and accountability of non-

\footnotetext{
6 'Modernisation', in part, means that essential public services (e.g. health, education, defence, utilities, social security)are now significantly managed, delivered and governed by private and third sector organisations (Broadbent and Guthrie, 2008). Broadbent and Laughlin (2005) argue that current government practices relate modernisation to the process of moving to something 'better' and therefore define modernisation by undertaking an analysis of government practices.

${ }^{7}$ One approach to EA is Environmental Management Accounting (EMA), which is the generation, analysis and use of financial and related non-financial information in order to integrate corporate environmental and economic policies, and build sustainable business (Bartolomeo et al., 2000). It seeks to separately identify environment related costs and revenues within the conventional accounting systems (Gray \& Bebbington, 2001) such as through the application of Activity Based Costing (ABC) (Quarles \& Stratton, 1998).
} 
metropolitan urban water utilities (NMUs) in 2000 observed that there was little incentive for NMUs to practice water conservation as revenue is tied to the amount of water sold and a reduction in usage will reduce the financial performance of NMUs (VAGO, 2000).

Evidence of the adoption of EA practices in the public sector in Australia up until 2001 was limited to NSW (Gibson \& Guthrie, 1995; Frost \& Toh, 1998a, 1998b; Frost \& Seamer, 2002) and the Commonwealth public sectors (Burritt \& Welch, 1997a, 1997b) and local government in Victoria (Douglass, 1996). Within the NSW public sector, Gibson and Guthrie (1995) observed that 36\% of the NSW public sector sample organizations with environmental disclosures in the annual report (EDARs) included financial information. Subsequent to this study, Frost and Toh (1998a) identified that the adoption of EA procedures by NSW public sector entities was: 1) motivated by the perceived importance of environmental issues by key personnel; 2) a function of the manager's personal beliefs and the importance of environmental issues to the entity; and 3) motivated by the environmental sensitivity of the entity's activities (Frost \& Toh, 1998a). Frost and Seamer (2002) observed: 1) an EMS may be developed and externally accredited without the corresponding development of EA practices; and 2) water and energy utilities are more likely to have developed internal management procedures.

Up until 2001, there has been recognition of the importance for both public and private sector entities to develop EA practices to account for externalities. Within the Commonwealth public sector, Burritt and Welch (1997a, p.73) highlighted the importance for public sector entities to account for externalities due to an expectation that "public costs and benefits" should be "the focus of attention". Whilst not referring directly to water, Parker (2000b, p.50) highlighted that "communities and governments will press for cost estimates of the externalities of organisations' environmental impacts”.

\section{Public sector "modernization and the Victorian water industry}

Public sector reforms and the resulting reforms of the water industry in Australia in the 1980s were a part of a move towards the New Public Management (NPM) (Hood, 1995). NPM sought to reduce and remove the differences between the public and the private sector (Hood, 1995, p.94), a central feature of which was the 'financial management' and accounting techniques drawn upon in the pursuit of reform (Guthrie et al., 1999, p. 210). Victoria was at the forefront in the adoption of NPM reforms in Australia (English \& Guthrie, 2001; Carlin, 2003) and therefore modernization reform of the water industry.

Victorian Financial Management Reforms in the period 1981 to 2001 were characterized by four phases: 1 . Traditional phase (prior to 1982); 2. Managerialist phase (1982 - 1992); 3. Marketization phase (1992 - 1997); and 4. Strategic phase (since mid-1997) (English \& Guthrie, 2001). As Victorian water utilities are owned and operated by the State of Victoria, Victorian Financial Management, or "Modernisation", reforms, would therefore directly impact upon the financial management of Victorian water utilities. Table 1 outlines the phases of Victorian Financial Management Reforms. 
The Australasian Accounting Business \& Finance Journal, February, 2008. Moore: Transformation of the Australian Public Sector and Environmental Accounting Practices. Vol. 2, No. 1.

Table $1 \quad$ Victorian Financial Management Reform Phases

Phase

Traditional

Managerialist

Marketization

Strategic

\section{Emphasis}

Cash accounting, controls over inputs, reliance on budgetary, executive and Westminster parliamentary systems Private sector management techniques, accrual accounting for external reporting and management purposes.

Combination of managerialist ideas with economic theories that emphasise individualistic self-interest, competitive markets and contracts, identification of the results to be achieved by managers and how managers were to be held accountable

'Whole of government' strategies with regard to strategic planning, management and financial reporting

Source: Adapted from English \& Guthrie (2001).

The traditional phase of modernization reform put the restructure of the Victorian water industry on the agenda when in 1981, the Parliament of Victoria Public Bodies Review Committee $^{8}$ recommended that water authorities be structured to achieve the twin objectives of efficiency and accountability (The Parliament of Victoria, 1981, pp.11 - 12). This required that future structures of the water industry be evaluated on the basis of: 1 . the efficient management of water; 2. the efficient use of limited capital; 3. accountability; 4. community needs; and 5. harmony with environmental standards (The Parliament of Victoria, 1981, pp.13-14). An emerging role for accounting in the management of water utilities was recognized as there was imbalance in regulatory oversight at the time towards engineering, with a neglect of financial management (The Parliament of Victoria, 1981, p.41). A role for accounting for water was beginning to emerge in 1981 as it was recommended that future regulatory oversight of local water and sewerage authorities be concerned with social, economic and financial implications as well as engineering aspects" (The Parliament of Victoria, 1981, p.41).

The recognition of the emerging role for accounting within the traditional phase was evident in the second phase of modernization reform in the Victorian public sector, the "managerialist phase" (1982 - 1992). The "managerialist phase" was characterized by attempts to introduce private sector management techniques such as accrual accounting (Carpenter, 1990; Guthrie, 1998; English \& Guthrie, 2001) as well as the rationalization of Victorian water authorities from over 400 in 1982 to approximately 140 in 1993 (VAGO, 2000). The managerialist phase sought to promote efficiency, effectiveness, cost savings and accountability (Broadbent \& Guthrie, 1992; Parker \& Guthrie, 1993; Guthrie \& Johnson, 1994).

Accountability structures and decision making within the Victorian public sector and therefore the water industry were significantly reshaped as a result of the election of a conservative government in 1992 and the resulting Victorian Commission of Audit (VCA)

\footnotetext{
${ }^{8}$ The Parliament of Victoria Public Bodies Review Committee released a report in 1981 examining the future structures of water management in Victoria (The Parliament of Victoria, 1981).

${ }^{9}$ Managerialism was based upon a philosophy of individualism and self-interest which proposed the devolution of responsibility for managers (Guthrie, 1992, 1993; Funnell \& Cooper, 1998; Pollitt, 1998).
} 
reports and public management policies (PMP) (English \& Guthrie, 2001). This was the beginning of the "marketization phase" (1992 - 1997) of modernization reform in the Victorian public sector (English \& Guthrie, 2001). The VCA report required that the focus for decision making and accountability within the Victorian public sector, and therefore water utilities, be driven by a fully-costed output model (English \& Guthrie, 2001, p.48). The importance of knowing the "full costs" 10 of programs and services highlighted the limitations of cash-based accounting systems, as reported expenditure would not reflect the cost of the program (Carpenter, 1990). This approach to measuring and understanding the "full costs" of programs and services differs from the full (environmental) costs as the price of the relevant inputs may not include their opportunity cost to society (see Renzetti \& Kushner, 2004). A key phase of the "marketization phase" in Victoria was the introduction of several financial management acts (English \& Guthrie, 2001), such as the Financial Management Act $1994^{11}$. Section 51 of this Act provides the relevant Minister ${ }^{12}$ with discretionary powers to direct a public body to include in financial statements additional information (The Parliament of Victoria, 1994), such as the provision by NMUs of segmented financial data (RWA, 2000). The focus was therefore on external financial reporting. The "marketization phase" of public sector reform corresponded with the establishment of an Independent Committee of Inquiry into a National Competition Policy (NCP), known as the Hilmer Report by COAG (Commonwealth of Australia, 1993). The Hilmer Report recommended the adoption of inter-governmental agreements for the structural reform of State and Territory Government owned businesses (Commonwealth of Australia, 1993), such as the adoption by COAG in February 1994 of a strategic framework for the reform of the Australian water industry (NCC, 1998, 1999). Key elements of the framework were cost reform and pricing, which required the implementation by water utilities of consumption based-based pricing and full-cost recovery ${ }^{13}$, as well as the reduction and elimination of cross-subsidies (NCC, 1999).

In mid-1997, the fourth phase of "modernization" reform in the Victorian public sector, the "strategic phase", commenced which was characterized by the adoption of accrual accounting and the allocation of funds to departments based on outputs delivered in accordance with fullycosted budget targets (English \& Guthrie, 2001). At a commonwealth level, reform of the water industry in 1998 began to recognize the importance of the environment and the need for EA procedures. The importance of accounting for externalities (societal costs) in the Australian water industry was highlighted by an expert group on asset valuations and cost recovery methods which recommended that for a water business to be viable, it should recover externalities ${ }^{14}$, in

\footnotetext{
10 The Productivity Commission defined the "full cost" of a unit of product as the value of all resources used or consumed in the provision of the product such as direct labour, direct materials and services, indirect labour, indirect materials and services, accommodation charges and capital costs (PC 2001, p. H.4)

${ }^{11}$ The introduction of the Financial Management Act 1994 coincided with the adoption by the Commonwealth of corporate type structures for Public Business Enterprises (see, Guthrie, 1993)

12 The Minister for Environment and Conservation, Victoria, appoints the Board of Directors for non-metropolitan Victorian regional water authorities (NMUs) and makes directions to water authorities regarding disclosure of financial information (RWA, 2000).

${ }^{13}$ Full cost recovery requires that a water business must price between a floor price that allows for the continuing commercial viability of the system and a ceiling price which incorporates asset values and a rate of return but does not include monopoly profits (NCC, 1999a). Within this band, a water business should not recover more than operational, maintenance and administrative costs, externalities, taxes or tax equivalent regimes, interest costs on debt and dividends (NCC, 1999a)

${ }^{14}$ Externalities were defined by the expert group as environmental and natural resource management costs attributable to and incurred by a water business (NCC, 1998, p.113). Three methods of valuing externalities are: 1)
} 
addition to operational, maintenance and administrative costs (NCC, 1998, p.112). An assessment by the National Competition Council (NCC) ${ }^{15}$ in 2001 of water reform in Victoria observed that Victorian NMUs “do not appear to make explicit provisions for externality charges” (NCC, 2001, p.34). The recognition by the Commonwealth of the need for water businesses to account for externalities preceded two separate Victorian parliamentary inquiries into EA and reporting, both of which recognized the importance of EA and an EMS (The Parliament of Victoria, 2000, 2002).

Up until the start of the twenty first century, the "modernisation" reforms of the state and commonwealth public sectors, and therefore the water industry, in Australia and Victoria emphasised efficiency, decentralisation, and cost recovery, as well as the implementation of private sector management techniques, competitive markets and contracts, 'whole of government' strategies and the full costing of outputs. Within this context, the limited adoption of EA procedures has taken place within the NSW public sector and Victorian local government. Given the recognised importance in 2000 and 2002 of EA by the Parliament of Victoria (The Parliament of Victoria, 2000, 2002) and the recognition by the NCC of the need for water businesses to recover externalities (NCC, 1998), this study seeks to explore the implications of Victorian public sector modernisation reforms for accounting for water within the Victorian water industry. To answer this question, a case study was undertaken of a Victorian NMU.

\section{RESEARCH METHOD}

Existing research into the adoption of EA practices in the Australian public sector has been based upon survey (Frost \& Toh 1998a, 1998b; Frost \& Seamer, 2002) and case study data (Douglass, 1996). Apart from EA, Hoque (2005) undertook a case study to examine the impact of NCP and the Local Government Act upon the internal practices of a large Australian local authority. A case study was chosen as it can provide a better understanding of the role and function of accounting in organizations (Humphrey \& Scapens, 1996), such as the integration of the accounting system and environmental management in the public sector (Frost \& Toh, 1998a).

The case study organisation was a public sector regional water authority, known as Regional Water Authority (RWA) located in Victoria, Australia. At the time, the Victorian water industry was separated into five categories of operational water businesses in 2001: 1) catchment management authorities; 2) metropolitan wholesale water; 3) metropolitan distribution and water retail authorities; 4) rural water authorities; and 5) non-metropolitan urban water authorities (NMU) (VAGO, 2000). RWA, an NMU, was chosen as it is responsible for the treatment and discharge of effluent into coastal waters, which was the major environmental issue facing the metropolitan and regional urban water businesses (NCC, 2003). For external reporting purposes, RWA consisted of two segments: 1) Retail - collection, treatment and supply of high quality

the avoidance cost method; 2) the cost of damages method; and 3) the collective consent to pay method (Antheaume, 2004).

15 The National Competition Council (NCC) was established on 6 November 1995 by the Competition Policy Reform Act 1995 following agreement by the Commonwealth, State and Territory governments in Australia (NCC, 2001). It is a federal statutory authority which functions as an independent advisory body for all governments on the implementation of the National Competition Policy reforms (NCC, 2001). 
water; collection, treatment and disposal of sewerage. There are three segments within retail: water, sewerage and waterway. 2) wholesale - harvesting and collection of water (RWA, 2000).

At the time of the case study, there was a complex governance structure for RWA. As an NMU, RWA was a statutory authority under the Water Act 1989 and the Victorian Minister for Environment and Conservation is primarily responsible for the Victorian water industry, including the NMU sector (VAGO, 2000). In 2001, the Environmental Protection Authority (EPA) was responsible for oversight of water industry environment compliance under the Environment Protection Act 1970 whilst the Department of Treasury and Finance set borrowing levels, dividend policies and financial matters under the Public Authorities (Dividends) Act 1983 , the Borrowing and Investment Powers Act 1987 and the Financial Management Act 1994 (VAGO, 2000).

RWA has four internal divisions as part of its corporate structure: customer services, strategy and technology, water systems and business performance. The strategic planning department, located within the strategy and technology division, was responsible for capital budgeting and the operation of the EMS. The sewerage operations department, located within the water systems division, was responsible for the operation of the sewerage treatment plants. The business planning and reporting department, located within the business performance division, was responsible for the operation of the management accounting system. The financial services department, located within the business performance division, was responsible for the financial accounting function.

For the case study, two sources of evidence were used, documentary evidence and interviews. Prior to, and during, the interviews, the researcher obtained the following documentary evidence:

- RWA Annual Report 1999 2000;

- RWA Chart of Accounts;

- A data base list of departments and code numbers within RWA;

- Sewer Segment Operating Statement June 30, 2000;

- Segmented Operating Statement RWA, June 30, 2000;

- Department of Natural Resources and the Environment (DNRE) 2001 Price Review of Water, Drainage and Sewerage Services in Victoria.

This evidence provided details to corroborate information obtained from the interviews, specifically the identification and examination of: (1) How costs are classified and measured (traced and allocated) within and between segments of RWA; (2) How costs are classified and measured (traced and allocated) within and between the departments within the segments; (3) The Acts of Parliament that govern regulations that affecting both the EMS and the MAS and (4) The performance measurement system.

The primary form of data collection comprised eight semi-structured interviews undertaken in 2000 and 2001. Table 2 details the approach taken to the selection of staff to be interviewed and interviewing procedures adopted: 
The Australasian Accounting Business \& Finance Journal, February, 2008. Moore: Transformation of the Australian Public Sector and Environmental Accounting Practices. Vol. 2, No. 1.

Table 2 Interviews ${ }^{16}$

\begin{tabular}{|c|c|c|c|c|c|}
\hline Interviewees & How & Style & No. & $\begin{array}{l}\text { Data } \\
\text { Recording }\end{array}$ & Purpose \\
\hline \begin{tabular}{l}
\multicolumn{2}{c}{ Manager, Strategic } \\
Planning, Manager, Sewerage \\
Operations, Economist, \\
Strategic Planning
\end{tabular} & On Site & $\begin{array}{l}\text { Open } \\
\text { Ended }\end{array}$ & 1 & Notes & $\begin{array}{l}\text { To obtain the } \\
\text { authority's permission to } \\
\text { participate in the project } \\
\text { and provide an overview } \\
\text { of the nature and scope } \\
\text { of the project. }\end{array}$ \\
\hline $\begin{array}{l}\text { Chairman, Water } \\
\text { Authority. }\end{array}$ & Tel. & $\begin{array}{l}\text { Open } \\
\text { Ended }\end{array}$ & 2 & Notes & $\begin{array}{l}\text { To obtain the } \\
\text { authority's permission to } \\
\text { participate in the project } \\
\text { and provide an overview } \\
\text { of the nature and scope } \\
\text { of the project. }\end{array}$ \\
\hline $\begin{array}{l}\text { Executive Manager - } \\
\text { Business Performance }\end{array}$ & $\begin{array}{l}\text { On site } \\
\text { / Tel. }\end{array}$ & $\begin{array}{l}\text { Semi } \\
\text { Structured }\end{array}$ & 2 & Notes & $\begin{array}{l}\text { To provide an } \\
\text { overview of the } \\
\text { information } \\
\text { requirements for the } \\
\text { research and determine } \\
\text { the relevant personnel to } \\
\text { be interviewed. Obtain } \\
\text { the manager's view as to } \\
\text { the effectiveness of the } \\
\text { accounting system. }\end{array}$ \\
\hline $\begin{array}{l}\text { Manager - Business } \\
\text { Planning and Reporting }\end{array}$ & On site & $\begin{array}{l}\text { Semi - } \\
\text { Structured }\end{array}$ & 2 & $\begin{array}{l}\text { Tape and } \\
\text { notes. }\end{array}$ & $\begin{array}{l}\text { To examine the } \\
\text { management accounting } \\
\text { system as to how it } \\
\text { generates financial and } \\
\text { non-financial } \\
\text { information with regard } \\
\text { to effluent treatment. }\end{array}$ \\
\hline $\begin{array}{l}\text { Manager - Strategic } \\
\text { Planning and Economist - } \\
\text { Strategic Planning }\end{array}$ & On site & $\begin{array}{l}\text { Semi } \quad- \\
\text { Structured }\end{array}$ & 1 & $\begin{array}{l}\text { Tape and } \\
\text { notes. }\end{array}$ & $\begin{array}{l}\text { To examine the } \\
\text { EMS and the capital } \\
\text { expenditure process. }\end{array}$ \\
\hline
\end{tabular}

Interviews were transcribed and analysed by the researcher which represented a form of pattern matching. A detailed account of the case study results are presented in the following section.

${ }^{16}$ A detailed overview of the interview schedule identifying the interviewees and the purpose of each interview is contained in Appendix A. The interview questions are available upon request from the author. 


\section{THE RWA CASE}

RWA, one of Victoria's largest NMUs, was constituted in February 1994 with a history that can be traced back to 1908 (RWA, 2000). In 2001, it was responsible for the provision of water and sewerage services to a permanent population of almost 250,000 people (RWA, 2000). RWA manages ten water storages, eight water treatment plants and nine sewage treatment plants. Its vision was to be leading provider of quality customer services in the water industry whilst its mission statement stated:

RWA exists to provide water, sewerage and environmental management services in an efficient, costeffective and environmentally responsible manner, meeting the needs of our customers in an increasingly competitive business environment. (RWA Annual Report 1999 2000, p.3).

By 2001, RWA had undergone significant reform over the previous decade as a result of Victorian public sector modernization reforms, particularly the managerialist, marketization and strategic phases, as well as the 1994 COAG water reforms. After RWA agreed to participate in the case study, the first interview was with the manager responsible for oversight of the management and financial accounting functions. The interview emphasized that whilst there had been an increased role for accounting as a result of the public sector reforms, its limitations were recognized. Specifically, the manager explained that financial performance measures were "not appropriate for meeting community expectations" and therefore "it was not correct to be judged on financial performance measures". Significantly, the manager explained that there was an "emerging understanding" that the "traditional approach" of "returning a profit to government" was "not relevant" for RWA. However, the requirements of the Financial Management Act 1994 had the effect of requiring RWA to "operate like a corporate body". The manager explained that government regulations were a problem due to "the unclear expectations by the government".

The case study seeks to explore the implications of Victorian public sector modernisation reforms for accounting for water within the Victorian water industry. Sections 4.1 and 4.2 examine the managerialist phase of public sector reforms and their implications for accounting for water within RWA. Section 4.3 examines the marketization phase of reforms and their implications for accounting for water within RWA. Section 4.4 summarizes the implications of public sector modernisation reforms for the adoption of EA practices with regard to water.

\section{The managerialist phase - efficiency}

The managerialist phase of Victorian public sector modernisation reforms $(1982-1992)$ promoted efficiency, effectiveness, cost savings, accountability and devolution of responsibility (Broadbent \& Guthrie, 1992; Parker \& Guthrie, 1993; Guthrie \& Johnson, 1994; Pollitt, 1998). The principles of efficiency and devolution of responsibility were evident at RWA when the manager, strategic planning, explained that in his previous role as sewerage operations manager, he was "the owner of the asset", in this instance, the sewerage treatment plants, with the purpose of managing them efficiently:

(As) the sewerage operations manager, I was the owner of the asset. At the end of the day, the decision had been made by the organization. This is the type of plant you're going to get, go away and run it, and run it as efficiently as possible. This is our anticipated costs, so that's the basis of our budget to start with. That's refined to find out what it actually costs to operate (Manager, Strategic Planning - 27/7/01) 
The emphasis upon managing sewerage treatment plants as efficiently as possible is evidence of the impact of the managerialist phase of Victorian public sector modernisation reforms (Broadbent \& Guthrie, 1992; Parker \& Guthrie, 1993; Guthrie \& Johnson, 1994; English \& Guthrie, 2001). In order to improve efficiency, RWA employed internal contractors to undertake maintenance throughout the sewerage and water system. Specifically, the manager, strategic planning, explained that RWA has attempted to improve environmental performance at sewerage treatment plants through increased efficiency, by making service providers accountable on the basis of performance response times and repair times:

Those service providers have been really driven on performance response times and repair times. We're trying to improve environmental outcomes via the more competent and responsive maintenance and service providers. (Manager, Strategic Planning - 27/7/01)

RWA has also attempted to improve environmental performance through the introduction of an environmental management initiative:

One of the things which we've done is that trade waste, which is associated with the treatment plants, we're now introducing user pays which is based on the quality of effluent discharged to the sewer. The better quality effluent pays a lesser fee, so it's a polluter pays process for that. Businesses now have the opportunity to look at their costs and say, it's now worthwhile for us to invest in a pre-treatment process, so we're not discharging the more higher strength waste into our sewerage system. So cost recovery is driving, that's one clear environmental thing that we've tried to improve on (Manager, Strategic Planning - 27/7/01)

The adoption of an environmental management initiative at RWA, a user pays system for trade waste, is an example of how managerialism, specifically the devolution of responsibility, can lead to the introduction of initiatives such as efficiency-based environmental measures (Burritt \& Welch, 1997a). Within the Spanish electricity industry, the adoption of environmental management initiatives required the accounting function to be more integrated with the environmental strategy (Larrinaga-Gonzalez \& Bebbington, 2001).

\section{The managerialist phase - private environmental costs and devolution of responsibility}

An objective of the mangerialist phase of public sector modernization $(1982-1992)$ was for managers to be held accountable against clearly defined objectives (Guthrie, 1993). This resulted in RWA recording private environmental costs, such as conventional (direct) costs and hidden regulatory costs within the general ledger as traceable costs within the classifications of direct expenses and corporate expenses for each sewerage treatment plant department within the sewer segment. The manager, business planning and reporting, explained the accounting treatment for regulatory compliance costs:

In terms of reporting compliance costs and how much it effectively costs the organisation to report to the EPA, we do not capture costs in that account. We don't actually have an account that we would call EPA compliance reporting costs, where we would charge the scientific costs and charge labour, we don't actually capture them in that manner. It's effectively just part of the function sewerage operations (Manager, Business Planning and Reporting - 27/8/01)

EPA licence fees, a hidden regulatory cost, were traced to the cost centre, General Expenses, within the Direct Expenses category: 
The Australasian Accounting Business \& Finance Journal, February, 2008. Moore: Transformation of the Australian Public Sector and Environmental Accounting Practices. Vol. 2, No. 1.

In general expenses, there would be \$293000 for general expenses, and you can see \$245 000 is sitting within Black Rock as total general expenses. \$195,000 of that total, general expenses, purely relates to EPA licence costs (Manager, Business Planning and Reporting - 27/8/01)

Testing water quality for EPA regulatory compliance, a hidden regulatory cost, was traced to the cost centre, Business Centre Service Charge, within the Business Centre Charges Category. Managerialism, specifically, the devolution of responsibility (Guthrie, 1992; Parker \& Guthrie, 1993; Guthrie \& Johnson, 1994) was evident as the manager explained that department managers would negotiate a service level agreement at the start of the year with the scientific services department at RWA which determined the level of the business centre service charge for the water testing:

To measure the water quality is what the laboratory (scientific services department) does, and they have a service level agreement with water supply and charge water supply or water quality treatment for that function. Those types of charges that we are talking about are what we call service level agreements. At the start of the year, the managers between the lab and water supply, would sit down and the lab says, "Ok for the full year I am going to do 30\% of tests for sewerage operations, I'm going to do 5\% for waterways". They then work out a schedule of what they're going to need. And based on that, the lab has to fully recover its costs. It determines its charges to those service receivers based on the level of service they're going to provide. So the driver is the level of activity required (Manager, Business Planning and Reporting $11 / 7 / 01)$

The costs determined by these agreements represent an arbitrary, or predetermined average, charge for the provision of services, such as regulatory compliance testing:

It's a bit more arbitrary than that. We don't say to do one water quality charge, we need two hours of one person, we need \$10 of material and we need \$2 of electricity. We don't go to that level. It's more arbitrary than that. It’s a total cost based on an average (Manager, Business Planning and Reporting - 11/7/01)

The service level agreements represent a form of transfer pricing, whereby the cost of the environmental management department and the provision of EPA regulatory services, in the case of RWA, the Strategic Planning department, is charged to other departments within RWA. The accounting treatment for the private environmental costs at RWA and their integration into direct expenses and business centre charges cost categories, can compared to the observation by Parker (2000a, p.53) that "a propensity of companies (interviewed) tended to integrate most environmental costs into normal operating cost classifications" which made inquiries about environmental costing methods irrelevant.

The tracing of conventional and regulatory compliance costs, whilst they are not classified as environmental costs within the MAS at RWA, is consistent with the managerialist phase of public sector modernization reforms and its emphasis upon accountability for performance (Guthrie, 1993). Department managers were accountable and responsible for the budgeting of direct expenses. The manager business planning and reporting, explained this in further detail:

At the start of each year, each line manager budgeted for their direct costs based upon what they believe their activities are going to be for their section of the business and their understanding of what's happening (Manager, Business Planning and Reporting - 11/7/01)

The accountability of department managers for environmental performance was evident when the manager, strategic planning explained his accountability, whilst manager of the sewer segment, for a performance target, in this instance, sewer spills and overflows: 
The Australasian Accounting Business \& Finance Journal, February, 2008. Moore: Transformation of the Australian Public Sector and Environmental Accounting Practices. Vol. 2, No. 1.

You've got a target, performance target, to comply with your licence. This is the number of spills you've budgeted for, number of overflows, blockages, and here's the money to do it (Manager, Strategic Planning 27/7/01)

The manager strategic planning, previously the manager of the sewer segment and therefore responsible for the budgeting of direct costs, explained the budgeting process in further detail and highlighted the absence of guidelines to budget for the environmental impacts associated with effluent treatment and disposal:

Budgeting based on historic costs, what we've done in the previous year, what we're likely to do next year. There is provision made for all the monitoring programs, that's done under a service level agreement with a laboratory. But most of the budgeting is based on activity costs. So how much power we're going to use, what's our labour, how much chemicals we're going to use, all those types of activities. There's nothing that says to produce this quality of effluent, it's going to cost us this much to produce that quality effluent and the associated environmental impacts. It's not there, it's based on compliance, and activity based (Manager, Strategic Planning - 27/7/01)

When questioned about the accounting for environmental costs within corporate expenses category within the sewer segment, the Manager highlighted the emphasis to treat environmental costs as normal operating costs:

Only in the sense that corporate expenses include the overheads of all the other segments that come down to the water and sewerage segments, but that was only ever allocated at a high level in the sewerage area. It was not separated into the pipelines, the pump stations and treatment plants, it's just an overhead that comes into the segment. The only environmental component of the corporate overheads is the environmental management system which is operated outside the segment. So the EMS is run from here, there's a small portion of that. But not separated in any great way, into the segments (Manager, Strategic Planning 27/7/01)

The responses of the manager, strategic planning, are similar to the observation of Parker (2000a), that interviewees, when questioned on environmental costs, often returned to operational terminology and examples in their responses. In particular, Parker (2000a) observed that the understanding by managers interviewed of environmental costing concepts was suspect, due to the tendency to separately identify costs as "mining and processing costs", not "environmental costs". In the case of RWA, the mangerialist phase of public sector modernization reform, and its emphasis upon efficiency, meant that the identification of environmental costs was of secondary importance in the management of sewerage treatment plants. The emphasis upon accountability for direct costs at RWA is evidence of a public sector culture under the regime of NPM where there is pressure to decrease direct and total costs and become more efficient in order to accommodate increases in indirect (control) costs (Olson et al., 2001). By making managers more accountable for direct costs, the associated monitoring costs will increase. In summary, managerialism resulted in limited adoption of EA practices as private environmental costs, specifically conventional direct costs and hidden regulatory costs, were traced to responsibility centres, specifically departments within RWA. 


\section{The Marketization phase -segmented reporting}

The marketization phase of Victorian public sector modernization reform (1992 - 1997) was characterized by the introduction of new financial management and audit acts (English \& Guthrie, 2001) such as the Financial Management Act 1994. The Financial Management Act 1994, and the discretionary powers that it made available to the Minister for Environment and Conservation, resulted in RWA being segmented into three retail segments and one wholesale segment for external reporting. The manager, business planning and reporting, explained the relationship between the reporting requirements and the allocation of overhead costs to the segments in both interviews:

There are two main reasons for cost allocation, internal and external. The external reasons are our corporate planning requirements based on what the minister wants to know. The corporate plan must be completed in a certain way and that includes segmenting our business into its key areas: 1 . retail and 2. wholesale operations. Retail is broken down into 1. sewer, 2. water, 3. waterways and wholesale stays at wholesale (Manager, Business Planning and Reporting - 11/7/01)

The application of the discretionary powers of the Minister for Environment and Conservation at the time (2001) placed an emphasis upon segmented reporting, which resulted in overhead costs being allocated to each of the four segments within RWA, and not the departments within each segment. The allocation of overhead costs was primarily for the purpose of external segment reporting, as opposed to reporting monthly overhead cost variances in the allocation of overhead costs to the board of directors at RWA:

Generally, I'm certainly not saying that we're not interested in it internally. It's definitely something we look at. Here we can quite clearly see the sewer segment got \$1 800000 compared to the water segment of $\$ 2500$ 000, so we're definitely analysing the movements internally. From the previous year, they may move quite considerably. But general reporting, this is not something we would report to the board monthly (Manager, Business Planning and Reporting - 27/8/01)

In 2001, State Government Acts and Regulations contained no requirements for environmental disclosures in annual reports by government departments, and there were no accounting standards for the inclusion of environmental matters in public sector financial statements (The Parliament of Victoria, 2002, p. 167). An allocation of environment-related overhead costs would be contingent upon directions made by the Minister for Environment and Conservation in accordance with Section 51 of the Financial Management Act 1994 (RWA, 2000). This would be contingent upon recognition by the Minister for Environment and Conservation of the information needs of stakeholders apart from the State Government and the Parliament of Victoria, such as local communities and the Environmental Protection Authority. Within UK local government, the Central Government's national strategy for sustainable development identified the use of quality of life indicators as a central tool in operationalising sustainability which led to the development in 2001 of 23 quality of life indicators (Ball, 2005). Within Victoria, the absence of legal and accounting requirements for EA in 2001 is one factor that explains the limited adoption of EA practices. Failure by central government in the UK to provide resources for community strategy / well-being works to influence negative political pressures for EA change (Ball, 2005). 
A critical environmental costing issue for a water business is accounting for externalities, or social costs (NCC, 1998). Private environmental costs can be separated from direct cost accounts and indirect overhead accounts through the application of ABC (Quarles \& Stratton, 1998). However, accounting for externalities for water utilities is not an issue that can be resolved through the separation of environment-related costs from overhead accounts, but rather through the adoption of Full Cost Accounting (FCA) (Bebbington et al., 2001; Antheaume, 2004; Renzetti \& Kushner, 2004) or with a set of environmental taxes and levies (CSIRO, 2001). The marketization phase of Victorian public sector modernization reform (1992 - 1997) was focused upon measuring cost information for external reporting, as opposed to measuring the full economic (environmental) cost.

\section{The limited adoption of (environmental) accounting practices for water}

At the time of the case study, there were two environmental initiatives undertaken by RWA: 1. Re-use projects involving the reuse of reclaimed water from sewerage treatment plants and 2. the Green Industry Probe, implemented to investigate the feasibility of using reclaimed water (RWA, 2000). However, apart from these two initiatives, there was limited adoption of EA practices for water in 2001. Interviewees explained that one causal factor in the limited adoption of EA practices was the absence of measurement guidelines. The manager, business planning and reporting, highlighted the difficulty at the time for the MAS to measure environmental costs:

In terms of management accounting systems, it's very difficult to bring the links back at the moment. We've got nothing in there distinguishing a direct cost that's a direct cost because of an environmental impact, as opposed to a direct cost that is an operating impact. There's no accounting standards, there is nothing in the accounting literature to tell you how to do it (Manager, Business Planning and Reporting - 11/7/01).

The economist, strategic planning, acknowledged the difficulty of measuring environmental costs, specifically externalities, for RWA and public sector entities:

It's pretty difficult to actually quantify both environmental and social costs, and I think that's a major issue for all government trading enterprises. It doesn't matter if you're a government or non-government for that matter. We're going to improve the environmental flows of this particular river or this creek, which is going to have a positive benefit downstream. Now, how do you actually quantify that in terms of the improved benefits downstream? We definitely look at those environmental and social impacts, but we don't actually quantify them (Economist, Strategic Planning - 27/7/01)

The manager, business planning and reporting, subsequently observed that the adoption of EA practices for water was contingent upon measurement guidelines:

If we want to measure the cost of looking after our environment compared to just doing what we do, that's going to be lot more difficult to capture. And we need some measurement guidelines, that's the biggest accounting catch cry of all-time (Manager, Business Planning and Reporting - 11/7/01).

Frost \& Toh (1998a) identified that the adoption of EA practices in the NSW public sector was motivated by the perceived importance of environmental issues by key personnel. The manager, business planning and reporting, was yet to appreciate the benefits of the adoption of EA practices for water at the time (2001): 
The Australasian Accounting Business \& Finance Journal, February, 2008. Moore: Transformation of

In terms of dollars and cents, we're not saying at this stage that we believe all these costs are directly related to the environment or indirectly related to the environment. We could prepare some analysis and believe what we think is the case but at the moment, we're not working under that framework (Manager, Business Planning and Reporting - 11/7/01).

The response of the manager is consistent with the observation of Parker (2000a, p.53) that an "appreciation of the potential benefits to (an) organisation of more detailed and sophisticated environmental costing systems may yet take some time to develop”. In contrast, accountants within UK local government were supportive of reporting on sustainable development (Ball, 2005). Within the Spanish electricity industry, the adoption of EA initiatives could be facilitated if it was demonstrated to management that EA could yield positive operational improvements (Larrinaga-Gonzalez \& Bebbington, 2001).

In summary, the impact of Victorian public sector modernization reforms and their emphasis upon "efficiency" (Broadbent \& Guthrie, 1992; Parker \& Guthrie, 1993; Guthrie \& Johnson, 1994), suggests that the emphasis upon efficiency took precedence to the adoption of EA practices at RWA in 2001. The emphasis upon efficiency as opposed to the adoption of EA practices in 2001 may be explained by a Victorian Auditor-General's report into the performance and accountability of NMUs in 2000 which observed that there was little incentive for NMUs to practice water conservation as revenue is tied to the amount of water sold and a reduction in usage will reduce the financial performance of NMUs (VAGO, 2000). In addition, the drought was not as severe in 2001 as it was in 2006/07. In 2001, annual rainfall at RWA's key reservoirs was approximately 1000mm (RWA, 2007). In 2006, annual rainfall was approximately $600 \mathrm{~mm}$, which resulted in stream flows reducing to 50 per cent of the past 10-year average (RWA, 2007). The worsening drought conditions between 2001 and 2006 combined with state government policy initiatives subsequent to 2001 has seen the emergence of the sustainability phase of public sector reform, the next phase of the modernization process of moving to something 'better' (Broadbent and Laughlin, 2005).

The present study explored the implications of Victorian public sector "modernisation" reforms for accounting for water within the Victorian water industry. The "managerialist phase" of public sector modernisation reform, and its emphasis upon "efficiency" resulted in an emphasis upon managing sewerage treatment plants "as efficiently as possible". To improve efficiency, RWA employed internal contractors to undertake maintenance throughout the sewerage and water system. In an attempt to improve environmental performance through increased efficiency, RWA made the internal contractors accountable on the basis of performance response and repair times.

An objective of the "managerialist phase", accountability for performance, resulted in RWA recording private environmental costs within the general ledger as direct expenses and corporate expenses for the sewer segment. Managerialism was evident as department managers would negotiate a service level agreement to determine the cost of the testing of water quality for EPA compliance. Private environmental costs were therefore integrated into normal operating cost classifications, consistent with the observation of Parker (2000a). Further evidence of managerialism was evident as department managers were responsible for the budgeting of direct costs. Specifically, the manager, strategic planning, explained his accountability for an (environmental) performance target, sewer spills and overflows, as manager of the sewer 
segment. However, the emphasis was upon treating environmental costs as normal operating costs.

The "marketization phase" of the "modernization" reforms, specifically the Financial Management Act 1994, resulted in RWA being segmented into three retail segments and one wholesale segment for reporting. However, in 2001 the Financial Management Act 1994 contained no requirements for environmental disclosures and there were no Australian or government accounting standards for the inclusion of environmental matters in financial statements.

In 2001, there was limited adoption of EA practices at RWA. Evidence collected during the interviews suggests that the limited adoption of EA practices was due to the absence of measurement guidelines. Whilst there was recognition of qualitative improvements to the environment resulting from improved water and river quality, the staff interviewed were yet to appreciate the benefits of adopting EA practices and were unfamiliar with the potential for tracking a detailed breakdown of environmental costs. The emphasis upon efficiency took precedence to the adoption of EA practices. The absence of water specific measurement guidelines was identified by staff as a causal factor in the non adoption of EA practices whilst the pricing mechanisms in place did not provide incentives for NMUs to practice water conservation. Subsequent to undertaking the case study in 2001, developments in public sector reforms began to focus on accounting for externalities by water supply authorities. This is examined in section 5 .

\section{POSTSCRIPT: THE “SUSTAINABILITY PHASE” OF VICTORIAN PUBLIC SECTOR MODERNIZATION REFORMS AND ACCOUNTING FOR WATER}

Up to 2001, public sector modernisation reforms of the water industry had placed an emphasis on efficient performance. There was little emphasis within the "mangerialist", "marketization" and "strategic" phases of reform on sustainability management practices as the NCC highlighted that NMUs did not make explicit provision for externality charges and that the potential for a more explicit and consistent treatment be referred to the Essential Services Commission (NCC, 2001, p.34). Ball and Grubnic (2007, p. 250) highlight that the "government's role in developing legislative frameworks (that re-define) broad public policy objectives through the lens of sustainable development (SD) (is) crucial if we are to learn to live sustainably". The Victorian government redefined public policy objectives through the "lens of SD” in 2004 through the release of its Our Water Our Future White Paper (VGDSE, 2005). This was the beginning of the "sustainability phase" of public sector modernization reform in Victoria, or the process of moving to something 'better' (Broadbent and Laughlin, 2005), as the focus of the Our Water Our Future White Paper was the development of sustainable water strategies ${ }^{17}$, similar to the UK Central Government's national strategy for sustainable development (Ball, 2005). The aim of the Our Water Our Future White Paper was to deliver secure water supplies for Victorian rivers and acquifers, cities and towns and industries over the next 50 years (VGDSE, 2005). In particular, the release of the Our Water Our Future White Paper

\footnotetext{
${ }^{17}$ See http://www.ourwater.vic.gov.au/ourwater/about_our_water/the_victorian_government_central_region_sustainable_w ater_strategy
} 
corresponded with the worsening drought conditions as evident in 2006 with a reduction in stream flows to 50 per cent of the past 10-year average (RWA, 2007).

The Our Water Our Future White Paper sought to achieve “pricing for sustainability” by providing incentives for people to reduce water usage as well as implementing a policy that reflected the cost to the environment from harvesting water (VGDSE, 2005). The introduction of rising block tariffs in Melbourne has sought to provide an increased incentive for customers to use less water (VGDSE, 2005). In 2004, the Victorian Government sought to recognize the costs to the environment from the harvesting of water through the introduction of the Water Industry (Environmental Contributions) Act 2004. The purpose of the act was to make provisions for environmental contributions to be paid by water supply authorities (The Parliament of Victoria, 2004; RWA, 2005/6). Specifically, the Water Industry (Environmental Contributions) Act 2004 is a legislative, or regulatory attempt, to account for externalities (societal costs).

The environmental contributions paid by a water supply authority, which represent an environmental tax or levy (CSIRO, 2001), are collected for the purposes of funding initiatives that seek to: (a) promote the sustainable management of water; or (b) address adverse waterrelated environmental impacts (The Parliament of Victoria, 2004). Table 3 sets out the following environmental contributions to be paid by RWA from 2004 to 2008 as set out in the Act:

Table 3: Environmental contributions from 1 October 2004 to 30 June 2008

\begin{tabular}{|l|l|l|l|l|}
\hline $\begin{array}{l}\text { Water Supply } \\
\text { Authority }\end{array}$ & $\begin{array}{l}\text { 1 October } \\
2004-30 \\
\text { June 2005 }\end{array}$ & $\begin{array}{l}\text { 1 July 2005-30 } \\
\text { June 2006 }\end{array}$ & $\begin{array}{l}\text { 1 July 2006 - 30 } \\
\text { June 2007 }\end{array}$ & $\begin{array}{l}\text { 1 July 2007 - 30 June } \\
2008\end{array}$ \\
\hline RWA & $\$ 2760000$ & $\$ 3680000$ & $\$ 3680000$ & $\$ 3680000$ \\
\hline
\end{tabular}

RWA recognized and disclosed the "environmental contribution" as an expense from ordinary activities within its Operating Statement for the year ended 30 June, 2006. For the year ended 30 June 2006, RWA recognized and disclosed the environmental contribution as a \$ 3680 000 expense from ordinary activities whilst for the year ended 30 June, 2005, RWA recognized and disclosed the environmental contribution as a \$2 760000 expense from ordinary activities (RWA, 2005/06). RWA has allocated the Environmental contribution to the water and wastewater segments within the retail services segment (RWA, 2005/06).

Prior to the introduction of the "environmental contribution", the National Competition Council regarded the environmental contribution as an "important step towards ensuring water prices transparently reflect appropriate natural resource management costs (externalities)" (NCC, 2004, p. xvii). Subsequent to its implementation, the National Water Commission (NWC) ${ }^{18}$ made the following assessment in 2005 of the attempt by the environmental contribution to address externalities:

\footnotetext{
${ }^{18}$ Prior to the 2005 National Competition Policy (NCP) assessment by the NWC, assessments were carried out by the National Competition Council (NCC) (NWC, 2006).
} 
The Australasian Accounting Business \& Finance Journal, February, 2008. Moore: Transformation of the Australian Public Sector and Environmental Accounting Practices. Vol. 2, No. 1.

Victoria has not fully demonstrated the relationship between this levy and the environmental costs it addresses. Further, Victoria has not sufficiently demonstrated the extent to which the levy is used for resource management activities versus addressing environmental externalities. The Commission will continue to look for Victoria to demonstrate the extent to which the levy is used for resource management activities versus addressing environmental externalities (NWC, 2006, p.3.43)

However, the introduction of the environmental contribution did not correspond with the introduction of measurement guidelines to enable individual water authorities to recognise, measure and account for externalities. The absence of measurement guidelines in 2001 was still evident in 2006. In 2004, as a part of the NWI, the State and Territory governments within Australia agreed to continue to manage environmental externalities through a range of regulatory measures and to continue to examine the feasibility of using market based mechanisms such as pricing to account for positive and negative environmental externalities associated with water use (COAG, 2004).

The nature of a single case study limits the generalizability of the findings to RWA and other NMUs. The recognised importance for water supply authorities to account for externalities would be assisted by future experimental-based research into how the adoption of some form of FCA may enable the incorporation of information regarding externalities into the decision making process. In addition, existing research has tended to study EA at a single point in time, with less focus on developments over a period of time. Therefore, a longitudinal study may explain the relationship between institutional factors and the adoption of EA practices over time.

\section{REFERENCES}

Antheaume, N. (2004). Valuing External Costs - From Theory to Practice: Implications for Full Cost Environmental Accounting. The European Accounting Review 13, 443 - 464.

Ball, A. (2005). Environmental accounting and change in UK local government. Accounting, Auditing \& Accountability Journal 18 (3), 346 - 373.

Ball, A., \& Grubnic, S. (2007). Sustainability accounting and accountability in the public sector. In J. Unerman, J. Bebbington and B. O’Dwyer (eds.) (2007), Sustainability Accounting and Accountability (243 - 265). London: Routledge.

Ball, A., Broadbent, J., \& Jarvis, T., (2006). Waste management, the challenges of the PFI and 'sustainability reporting'. Business Strategy and the Environment 15 (4), 258 - 274.

Bartolomeo, M., Bennett, M., Bouma, J. J., Heydkamp, P., James, P. \& Wolters, T., (2000). Environmental Management Accounting in Europe: current practice and future potential. The European Accounting Review 9, 31-52.

Bebbington J., Gray R., Hibbit C., \& Kirk E. 2001. Full Cost Accounting: an Agenda for Action. Association of Chartered Certified Accountants, London.

Broadbent, J. \& Laughlin, R. (2005). The Role of PFI in the UK Government's Modernisation Agenda. Financial Accountability \& Management 21 (1), 75 - 97.

Broadbent, J.. \& Guthrie, J. (1992). Changes in the Public Sector: A Review of Recent "Alternative" Accounting Research. Accounting, Auditing \& Accountability Journal 5, 3 -31.

Broadbent, J.. \& Guthrie, J. (2008). Public Sector to Public Services: 20 years of 'Contextual' Accounting Research. Accounting, Auditing \& Accountability Journal, forthcoming.

Burritt, R.L. \& Welch, S. (1997a). Australian Commonwealth Entities: An Analysis of Their Environmental Disclosures. Abacus, 33 (1), 1 - 19.

Burritt, R.L. \& Welch, S. (1997b). Accountability for environmental performance of the Australian Commonwealth public sector. Accounting, Auditing \& Accountability Journal 10 (4), 532 - 561 
The Australasian Accounting Business \& Finance Journal, February, 2008. Moore: Transformation of the Australian Public Sector and Environmental Accounting Practices. Vol. 2, No. 1.

Carlin, T.M. (2003). Unravelling the Capital Charging Riddle- Some empirical evidence from Victoria. Financial Accountability and Management 19 (1), 73 - 92

Carpenter, G.J., (1990). Financial reporting by departments: developments in Victoria. In J. Guthrie, L. Parker and D. Shand (eds), The Public Sector Contemporary Readings in Accounting and Auditing Harcourt Brace Jovanovich. (222 - 233).

Cashman, A. and L. Lewis (2007). Topping Up or Watering Down? Sustainable Development in the Privatized UK Water Industry. Business Strategy and the Environment, 16, 93 - 105.

Council of Australian Governments (COAG) (2004). Intergovernmental Agreement on a National Water Initiative Between the Commonwealth of Australia and the Governments of New South Wales, Victoria, Queensland, South Australia, the Australian Capital Territory and the Northern Territory: 1 - 39.

CSIRO (2001) Pricing Water - a Tool for Natural Resource Management in the Onkaparinga Catchment. CSIRO Land and Water Policy and Economic Research Unit, December 2001.

Dalgleish, F., \& Cooper, B.J. (2005). Risk management: developing a framework for a water authority. Management of Environmental Quality, 16, 235 - 249.

Department of Natural Resources and Environment Victoria (DNRE). (2000). 2001 Price Review of Water, Drainage and Sewerage Services in Victoria Issues Paper (A process to determine new prices to apply from 1 July 2001). The Department of Natural Resources and Environment Water Sector Services Group Catchment and Water Division, Melbourne, Victoria.

Douglass, D. (1996). Environmental Accounting in Local Government: A Victorian Case Study, Best Practice Case Studies in the Public Sector., Melbourne: Australian Society of Certified Practising Accountants, 21-48.

English, L., \& Guthrie, J. (2001). Public Sector Management in the State of Victoria 1992-1999: Genesis of the Transformation. In L. R. Jones, J. Guthrie and P. Steane (eds) (2001), Learning From International Public Management Reform (45 - 60). New York: Elsevier Science Inc.

Frost, G.R., \& Seamer, M. (2002). Adoption of Environmental Reporting and Management Practices: An analysis of New South Wales Public Sector Entities. Financial Accountability and Management, 18, 103 - 127.

Frost, G.R., \& Toh, D. (1998a). A Study of Environmental Accounting within the New South Wales Public Sector. Accounting Research Journal, 11, 400 - 410.

Frost, G.R., \& Toh, D. (1998b). Environmental Accounting Practices and Management Attitudes: An Investigation of New South Wales Public Sector. Entities Accountability \& Performance, 4(3), 51 - 67.

Funnell, W., \& K. Cooper (1998). Public Sector Accounting and Accountability in Australia. Sydney: UNSW Press.

Gibson, R., \& Guthrie, J. (1995). Recent Environmental Disclosures in Annual Reports of Australian Public and Private Sector Organisations. Accounting Forum, 19 (2/3), 111 - 127

Gray, R., \& Bebbington, J. (2001). Accounting for the Environment. SAGE publications.

Guthrie, J. (1992)., Critical issues in Performance Measurement and Indicators. New Directions and Strategies for Financial Control in the Public Sector, Sydney, 20 \& 21 May 1992.

Guthrie, J. (1993). Australian Public Sector Accounting: Transformations and Managerialism. Accounting Research Journal, 6(2), 15 - 25.

Guthrie, J. (1998). Application of accrual accounting in the Australian public sector: rhetoric or reality?. Financial Accountability and Management, 14(1), 1 - 19

Guthrie, J., \& Johnston, M., (1994). Commercialisation of the Public Sector: Why, How and For What? A Prospective View. In K. Wiltshire (ed.), Governance and Economic Efficiency (pp. 87-108). Sydney: CEDA.

Guthrie, J., O. Olson, et al. (1999). Debating Developments in New Public Financial Management: The Limits of Global Theorising and some new ways forward. Financial Accountability and Management, 15(3 \& 4), 209 228.

Hood, C., (1995). The "New Public Management" in the 1980s: Variations on a Theme. Accounting, Organizations and Society 20(2/3), $93-109$

Hoque, Z. (2005). Securing institutional legitimacy or organizational effectiveness? A case examining the impact of public sector reform initiatives in an Australian local authority. International Journal of Public Sector Management 18(4), 367 - 382.

Humphrey, C., \& R. W. Scapens (1996). Methodological themes Theories and case studies of organizational accounting practices: limitation or liberation?. Accounting, Auditing \& Accountability Journal, 9(4), 86 - 106.

Institute of Chartered Accountants in Australia (ICAA). (2003) Environmental Management Accounting An introduction and case studies for Australia. Australia: ICAA.

Larrinaga-Gonzalez, C., \& J. Bebbington (2001). Accounting Change or Institutional Appropriation? A Case Study of the Implementation of Environmental Accounting. Critical Perspectives on Accounting, 12, 269 - 292.

Letza, S., \& C. Smallman (2001). In Pure Water there is a Pleasure Begrudged by None: On Ownership, Accountability and Control in a Privatized Utility. Critical Perspectives on Accounting 12, 65 - 85. 
The Australasian Accounting Business \& Finance Journal, February, 2008. Moore: Transformation of the Australian Public Sector and Environmental Accounting Practices. Vol. 2, No. 1.

Minichiello, Victor., Aroni, Rosalie., Timewell, Eric., \& Alexander, Loris. (1990). In-Depth Interviewing Researching People (Ist ed.). Longman Cheshire Pty Ltd.

National Competition Council (NCC) (1998). Compendium of National Competition Policy Agreements Second Edition.

National Competition Council (NCC) (1999) National Competition Council Annual Report 1998-99, National Competition Council: 1 - 30 .

National Competition Council (NCC) (1999a) Second Tranche Assessment of Governments' Progress with Implementing National Competition Policy and Related Reforms, Volume Two: Water Reform Assessments, National Competition Council.

National Competition Council (NCC) (2001). Assessment of Governments’ Progress in Implementing the National Competition Policy and Related Reforms: Victoria Water Reform, AusInfo, f., Canberra.

National Competition Council (NCC) (2003). Assessment of Governments' Progress in Implementing the National Competition Policy and Related Reforms: Volume three - Water reform, AusInfo, f., Canberra.

National Competition Council (NCC) (2004). Assessment of Governments' Progress in Implementing the National Competition Policy and Related Reforms: 2004 Volume two: Water, National Competition Council.

National Water Commission (NWC) (2005). Distilled The Monthly Newsletter from the National Water Commission, Issue 2, November 2005

National Water Commission (NWC) (2006). 2005 National Competition Policy Water Reform Assessment. Canberra, Commonwealth of Australia.

Ogden S.G. (1995a) Transforming frameworks of accountability: the case of water privatization. Accounting, Organizations and Society 20 (2/3), 193 -218.

Ogden S.G. (1997) Accounting for organziational performance: the construction of the customer in the privatized water industry. Accounting, Organizations and Society 22 (6), 529 -556.

Ogden, S. G. (1995b) Profit sharing and organizational change Attempts to promote employee commitment in the newly privatized water industry in England and Wales. Accounting, Auditing \& Accountability Journal 8 (4), $23-47$.

Ogden, S. G., \& R. Watson (1999). Corporate performance and stakeholder management: Balancing shareholder and customer interests in the U.K. privatized water industry. Academy of Management Journal 42(5), 526 - 538.

Ogden, S., \& J. Clarke (2005). Customer disclosures, impression management and the construction of legitimacy Corporate Reports in the UK privatised water industry. Accounting, Auditing \& Accountability Journal 18 (3), $313-345$.

Ogden, S.G., \& Anderson F. (1999). The Role of Accounting in Organisational Change: Promoting Performance Improvements in the Privatized UK Water Industry. Critical Perspectives on Accounting 10 (1), 91 - 124.

Ogden, S.G., \& R. Watson (1996). The relationships between changes in incentive structures, executive pay and corporate performance: Some evidence from the privatized water industry in England and Wales. Journal of Business Finance \& Accounting 23 (5,6), 721-751.

Olson, O., C. Humphrey, et al. (2001). Caught in an evaluatory trap: a dilemma for public services under NPFM. European Accounting Review, 10(3), 505 - 522.

Organisation for Economic Co-operation and Development (OECD) 1998. Environmental Performance Reviews, Australia. Paris: OECD.

Parker, L. D. (2000a). Green strategy costing: Early days. Australian Accounting Review 10, 46-55.

Parker, L. D., \& J. Guthrie (1993). The Australian public sector in the 1990s: New accountability regimes in motion. Journal of International Accounting, Auditing and Taxation 2(1), 59 - 81.

Parker, L.D. (2000b). Environmental costing: A path to implementation. Australian Accounting Review 10, 43-51.

Pollitt, C. (1998). Managerialism revisited. In B.G. Peters and D.J. Savoie (eds.), Taking Stock Assessing Public Sector Reforms. Montreal, Canada: Canadian Centre for Management Development, (pp.45-77).

Productivity Commission (PC) (2001). Cost recovery by Government agencies, Report no. 15. Canberra: AusInfo.

Quarles, R., \& Stratton, A. (1998). A case study using ABC to quantify environmental costs in plant operations. Journal of Cost Management 12(5), 23.

Regional Water Authority (RWA). (2000) RWA Annual Report 1999-2000.

Regional Water Authority (RWA). (2005 - 6) RWA Annual Report 2005 2006.

Regional Water Authority (RWA). (2007) RWA 2008 Water Plan October 2007. (pp. 1 - 141).

Renzetti, S., \& Kushner, J. (2004). Full Cost Accounting for Water Supply and Sewage Treatment: Concepts and Case Application. Canadian Water Resources Journal_29(1), 13-22.

Sadler, R. (1998). The Australian experience: managing a non-metropolitan urban water utility - paradigm shifting towards a new mindset. The International Journal of Public Sector Management 11, 596 - 610. 
The Australasian Accounting Business \& Finance Journal, February, 2008. Moore: Transformation of the Australian Public Sector and Environmental Accounting Practices. Vol. 2, No. 1.

Saunders, .M., P. Lewis, \& Thornhill, A. (2003) Research Methods for Business Students (Third ed.) Prentice Hall: Essex.

The Commonwealth of Australia (1993). National Competition Policy. pp. 1 - 268. Australian Government Publishing Service Canberra.

The Parliament of Victoria (1981). Public Bodies Review Committee Second Report to the Parliament Future Structures for Water Management Part 1: Regional and Local Administration. Melbourne: F.D. Atkinson Government Printer.

The Parliament of Victoria (1994) Financial Management Act 1994.

The Parliament of Victoria (2000). Follow-up Inquiry into Environmental Accounting and Reporting. Public Accounts and Estimates Committee, Parliament of Victoria, June 2000 (117 pages)

The Parliament of Victoria (2001). Inquiry into the Allocation of Water Resources. Environment and Natural Resources Committee, Parliament of Victoria, November 2001 (274 pages)

The Parliament of Victoria (2002). Final Report on Environmental Accounting and Reporting. Public Accounts and Estimates Committee, Parliament of Victoria, March 2002 (242 pages).

The Parliament of Victoria (2003). The Constitution (Water Authorities) Act 2003. The Parliament of Victoria.

The Parliament of Victoria (2004). The Water Industry (Environmental Contributions) Act 2004. The Parliament of Victoria.

Victorian Auditor-General's Office (VAGO) (2000) Non-metropolitan urban water authorities: Enhancing performance and accountability, November 2000 http://www.audit.vic.gov.au/reports_par/agp66cv.html [accessed: 12/2/2008].

Victorian Government Department of Sustainability and the Environment (VGDSE) (2005) Progress Towards Securing Our Water Future 04/05, (pp. 1 - 48).

Victorian Government Department of Sustainability and the Environment (VGDSE) (2006) Victorian State Water Report 2004/5 www.dpi.vic.gov.au [accessed: 12/2/2008].

Walker, R.G., Clarke, F.L., \& Dean, G.W. (2000). Use of CCA in the public sector: Lessons from Australia's experience with public utilities. Financial Accountability and Management 16, 1 - 32. 